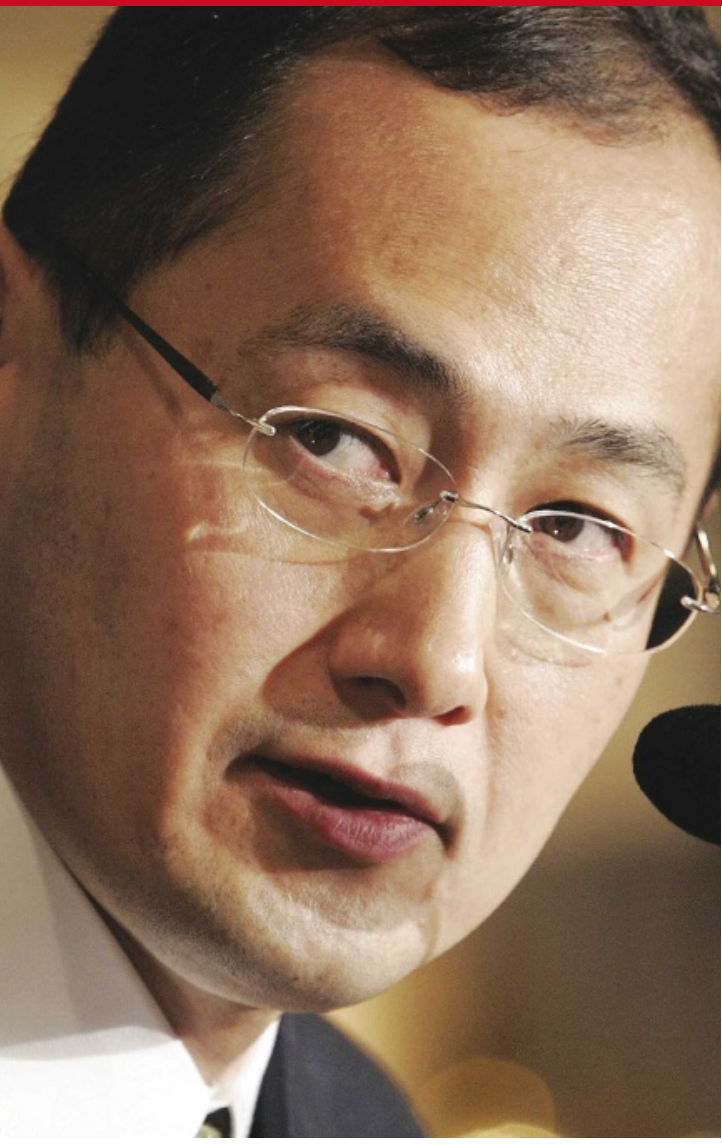

by Kleiner Perkins Caufield and Byers, the high-powered venture-capital company that helped create Genentech, and Highland Capital Partners. "iZumi is engaging in discussions with various potential partners," Kreiner says, and would not discuss the company's business model further. But on Monday, iZumi announced "a major research collaboration and licensing agreement to focus on applications for iPS cells" with Gladstone Institutes, based in San Francisco. Yamanaka has a joint position there.

Rumours abound in the normally conservative Japanese press. The magazine Nikkei Biotechnology \& Business reports that iZumi has been collecting "iPS cell patents from all over the world", and has already licensed ESand iPS-cell-related patents from Harvard University and the Massachusetts Institute of Technology (MIT) in Cambridge. Representatives of the intellectual-property office at MIT deny the report. Counterparts at Harvard say "we have no news to report" with regard to the patents. Kreiner says the patents in question have not even been issued. "It is clearly too early to discuss," he says.

"iZumi would like to work closely with Japan, and we celebrate Japan's scientific leadership," Kreiner told Nature. "Yamanaka and Sakurada as well as Thomson have made significant contributions," he says, acknowledging that it was Yamanaka's work on iPS cells in mice that was the starting point for the whole field. David Cyranoski

1. Takahashi, K. et al. Cell 131, 861-872 (2007)

2. Yu, J. et al. Science 318, 1917-1920 (2007)

3. Masaki, H. et al. Stem Cell Res. 1, 105-115 (2007)

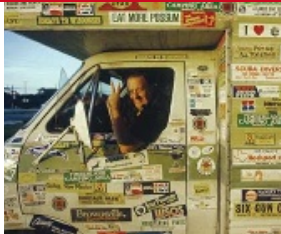

ALLTHE RAGE

Why bumper stickers are linked to aggressive driving. www.nature.com/news

\title{
Institutes in pharma cash probe
}

Until about three years ago, researchers at Duke University in Durham, North Carolina, declared their financial conflicts of interest by filling in a simple form. "It basically just asked: do you have a relationship with a company that might entail a conflict of interest?" says James Siedow, Duke's vice-provost for research.

The form has since been changed every year, becoming more complex with each new iteration. Now, Duke researchers are asked to estimate how much money they receive from industry sources. If that value is more than US $\$ 25,000$, they are required to delve into specifics. Although Siedow believes that most researchers filled in their forms accurately, he suspects that some were not forthcoming. “There were folks who didn't check that '\$25,000 or more' box, yet we're almost certain they should have," he says.

Pressure has been mounting on universities and hospitals to crack down on conflicts of interest. This month, Senator Charles Grassley (Republican, lowa) informed Congress that three high-profile psychiatrists at Harvard Medical School may have failed to disclose a total of about $\$ 4$ million of industry earnings over the course of seven years. Last August, Grassley disclosed that a researcher at the University of Cincinnati in Ohio had underreported industry earnings from a company that made a drug she had tested in clinical trials. And Grassley has informed the National Institutes of Health (NIH) that he is investigating other cases at more than 20 different institutions.

The NIH has made its stand on the issue clear: it is up to individual universities and hospitals to monitor their researchers, says deputy director of extramural research Norka Ruiz Bravo. The NIH may punish individual investigators by abridging or terminating their grants, but in cases where the misconduct seems to be systemic, sanctions could be levied against an entire institution.

But university administrators say they are unable to verify what their researchers disclose. "It's an honour system," says Robert Alpern, dean of the Yale School of Medicine. "We rely on the faculty to tell us the truth. And to be honest, up until a few months ago, I think we all thought they were telling us the truth."

Grassley has proposed legislation, called the Physician Payments Sunshine Act, that would require manufacturers of drugs and medical devices to disclose how much they pay doctors. The act would present institutions with a way to verify the sums their researchers have declared, and both the American Association of Medical Colleges and PhRMA, a lobbying group for the pharmaceutical industry, have praised the proposed act for increasing transparency. But the current draft of the legislation applies only to physicians and leaves out those researchers who do not practise medicine. Philip Pizzo, dean of Stanford Medical School, says he supports the act but acknowledges that it will come at a price. "This will not be an easy or inexpensive process," says Pizzo, who notes that schools may need to hire additional staff to process the new data.

Meanwhile, Siedow says that Duke administrators plan to interview researchers they suspect of not disclosing their earnings. Grassley's recent findings have bolstered Duke's efforts to improve its reporting system. "We can see the writing on the wall in Congress," says Siedow. "We don't want to find out from a pharmaceutical company that one of our researchers made half a million dollars that we didn't know about."

Heidi Ledford

See Editorial, page 957.

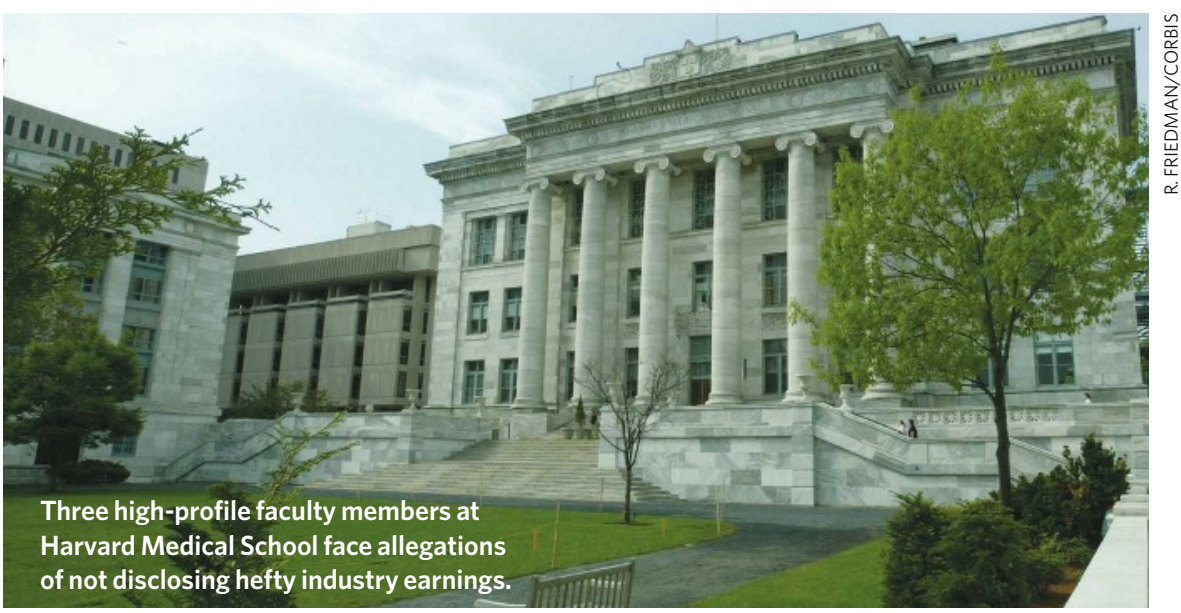

